\title{
GALLIUM-67 IMAGING IN A PATIENT WITH PARACOCCIDIOIDOMYCOSIS: A CASE REPORT
}

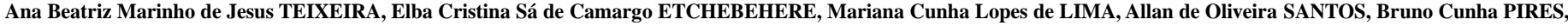
José Telmo VALENÇA JR., Celso Darío RAMOS \& Edwaldo E. CAMARGO

\begin{abstract}
SUMMARY
A 26 year-old female was admitted with abdominal pain, fever and weight loss. The clinical and laboratory investigations led to the diagnosis of paracoccidioidomycosis. Gallium- 67 whole body images correlated well with the clinical course of the disease and with the patient's prognosis.
\end{abstract}

KEY WORDS: Gallium-67; Paracoccidioidomycosis; Infection; Whole body scintigraphy.

\section{INTRODUCTION}

Paracoccidioidomycosis (South-American blastomycosis) is a disease caused by the dimorphic fungus Paracoccidioides brasiliensis, which was first described in 1908 by Lutz. Based on its pathogenesis the disease may be classified in the following forms: regressive (asymptomatic infection and primary pulmonary), progressive juvenile type (acute and subacute; pulmonary or disseminated) and progressive adult type (chronic; pulmonary or disseminated) ${ }^{4}$. Microscopic observation of $P$. brasiliensis in clinical samples and its isolation in culture are the most important diagnostic findings ${ }^{10}$. The double immunodiffusion and complement fixation serologic tests applied to paracoccidioidomycosis, which are the most commonly used, have allowed its early diagnosis and made it possible to manage the disease appropriately ${ }^{8}$. Radiological imaging of the skeleton, gastrointestinal tract and lungs have been used in the diagnosis and follow-up of these patients ${ }^{1,2}$. Whole body gallium67 scintigraphy has not been used routinely in the diagnosis and followup of patients with this disease.

The purpose of this report is to describe the whole body gallium-67 scintigraphic findings in a patient with paracoccidioidomycosis (juvenile disseminated form), with an atypical clinical course.

\section{CASE REPORT}

A 26 year-old farm worker female was admitted to the Campinas State University Hospital with a three-month history of abdominal pain, fever and weight loss. She presented with left cervical, bilateral axillary and inguinal lymphadenopathy and a $10 \times 10 \mathrm{~cm}$ mass in the right upper quadrant of the abdomen.

Chest radiograph was normal. Abdominal computed tomography and ultrasound showed massive ascites, retroperitoneal adenomegaly and thickening of the intestinal walls of the mid abdomen. Endoscopy revealed a fistula with a purulent secretion between the first and second portions of the duodenum.

Paracoccidioides brasiliensis was demonstrated in the direct microscopic examination of the duodenal secretion and the duodenal biopsy demonstrated Paracoccidioides brasiliensis (Fig. 1) as well as active chronic duodenal infection. Direct Ziehl-Neelsen microscopic examination was negative for acid-fast bacilli, and the Lowenstein-Jensen culture was negative for $M$. tuberculosis. Gomori-Grocott smears stains showed multiple budding yeast cells, characteristic of $P$. brasiliensis in the fine needle aspiration biopsy of the cervical lymph node. The ELISA anti-HIV serologic test was negative. The double immunodiffusion serologic tests for paracoccidioidomycosis were always negative.

Whole body gallium-67 scintigraphy (Fig. 2) revealed increased uptake in the abdomen, involving the peritoneum and intestinal wall, and in the left posterior cervical lymph nodes. These findings were interpreted as active disease.

Therapy was initiated with oral administration of sulfametoxazoltrimetoprim. Initially there was a good response that was followed by a significant clinical worsening. The patient presented several episodes of ascites. She was hospitalized and submitted to multiple large-volume paracenteses; cultures of the ascitic fluid were always negative for fungi (including $P$. brasiliensis) and mycobacteria. Amphotericin B therapy was started on (total dose: $4 \mathrm{~g}$ ). Creatinine serum levels became high and the patient began with a milky secretion attributed to the long term use of metoclopramide. A new whole body gallium-67 scintigraphy (Fig. 3 ) demonstrated active disease in the lungs and abdomen. There was also increased uptake of the radiotracer in the kidneys and breasts which

Division of Nuclear Medicine, Department of Radiology and Department of Pathology, Campinas State University, Campinas, Brazil.

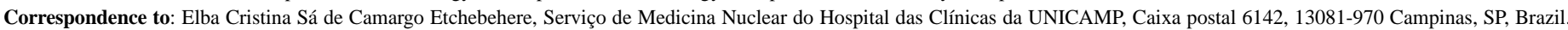
Phone : +55-19-2895973. Fax : +55-19-2511041. e-mail: elba@mn-d.com 

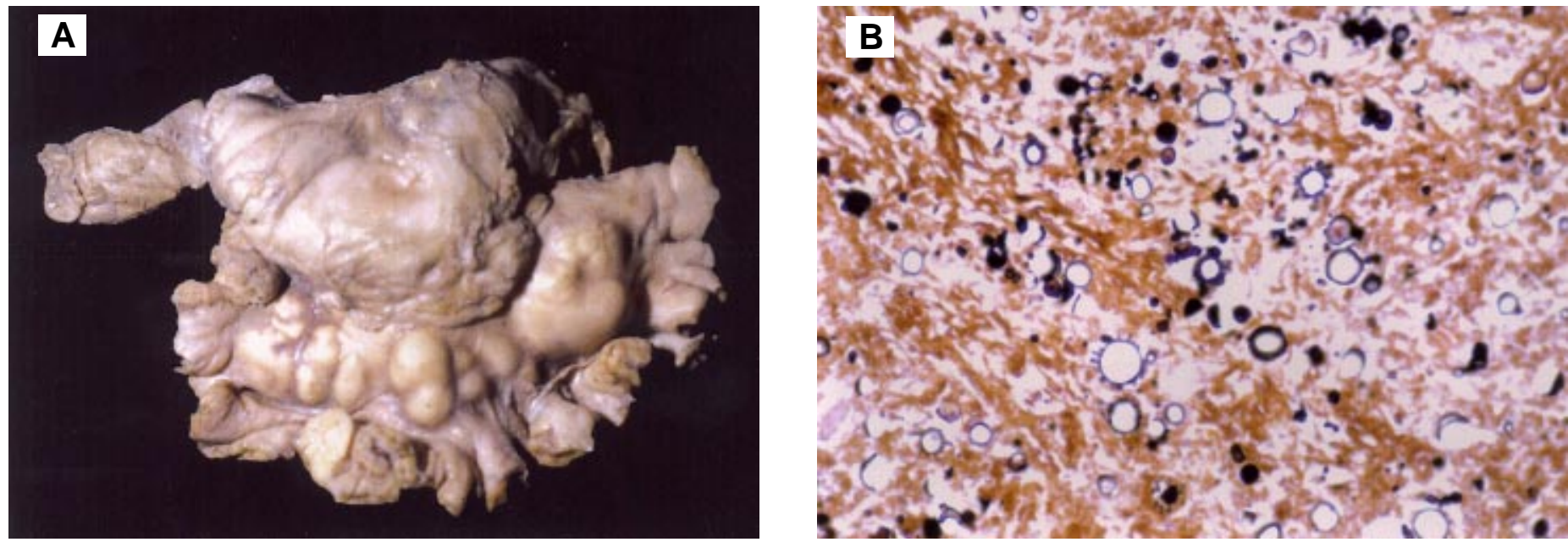

Fig. 1 - Duodenal biopsy demonstrating: A) massive and confluent mesenteric adenomegaly; B) multiple fungic structures with criptosporulation (Paracoccidioidomycosis). GOMORIGROCOTT 40x.

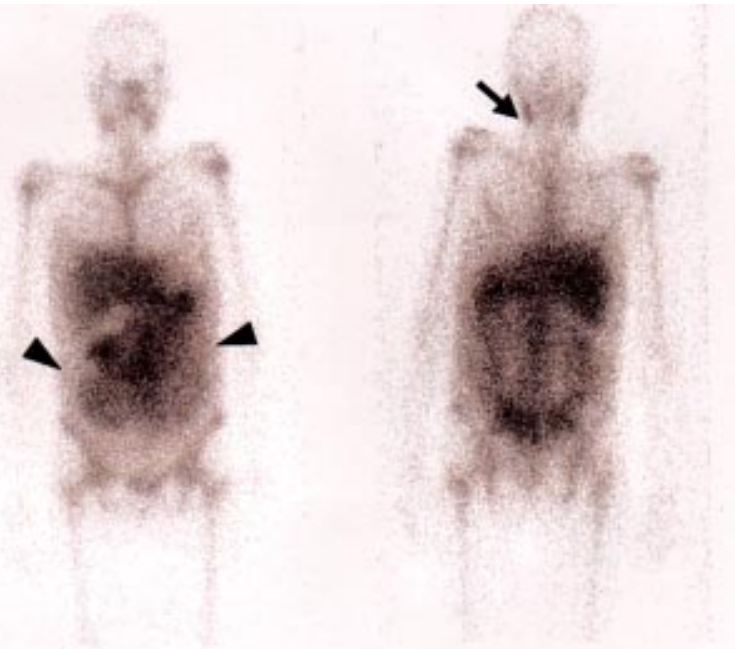

Fig. 2 - Whole-body gallium-67 scintigraphy (anterior and posterior views) obtained at the diagnosis reveals markedly increased uptake in the abdomen (arrow heads) and a left posterior cervical lymph node (arrow), interpreted as active disease in these areas.

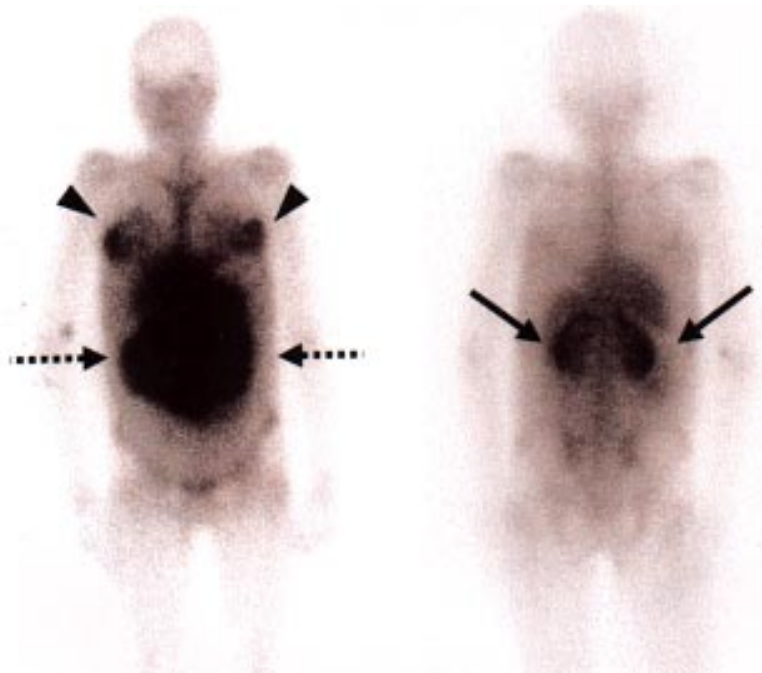

Fig. 3 - Whole-body gallium-67 scintigraphy (anterior and posterior views) obtained after the beginning of the treatment with amphotericin B and metoclopramide shows diffusely increased tracer uptake in the kidneys (arrows), breasts (arrow heads), lungs and abdomen (dotted arrows). The findings in the kidneys were interpreted as nephrotoxicity due to amphotericin B, the increased uptake in the breasts as side-effects from metoclopramide (the patient presented with milky secretion) and the uptake in the lungs and abdomen were interpreted as active disease. 


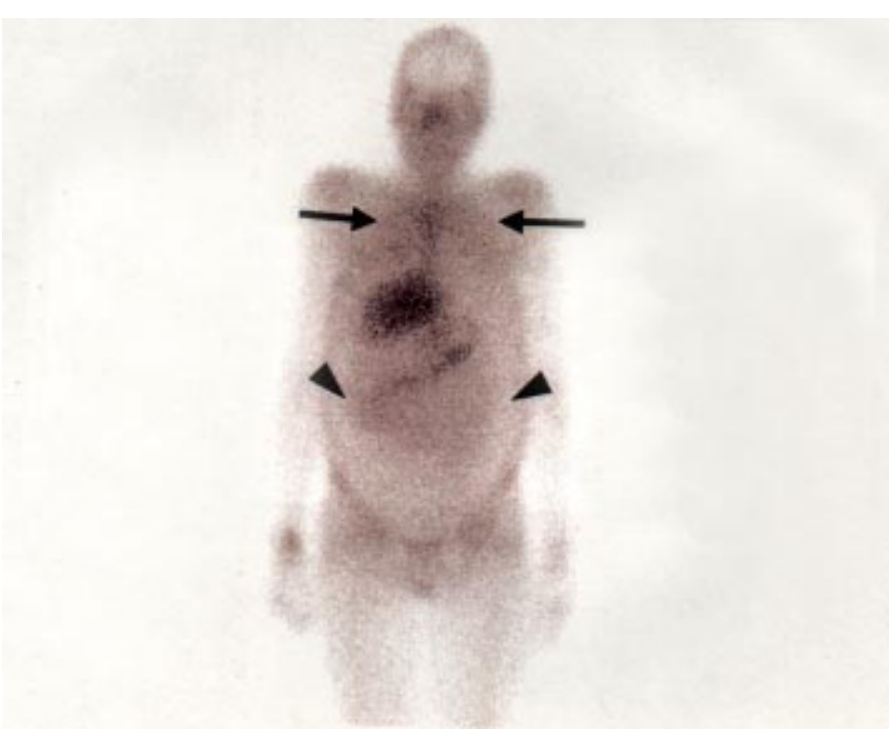

Fig. 4 - Whole-body scintigraphy (anterior view) obtained 20 months after the diagnosis shows persistently increased uptake of gallium-67 in the lungs (arrows) and abdomen (arrow head), indicating active infection.

were interpreted as nefrotoxicity caused by amphotericin B and stimulation of the breasts by metoclopramide, respectively.

Two other gallium-67 whole body scintigraphies (Fig. 4,5), obtained 20 and 31 months after the diagnosis, showed persistently increased uptake in the lungs and abdomen.

Thirty eight months after diagnosis and beginning of treatment, the patient was submitted to an exploratory laparotomy which showed a retroperitoneal mass. Biopsy demonstrated P. brasiliensis by Periodic acid-Schiff stain and Gomori-Grocott techniques.

In spite of appropriate therapy, which also included the association of itraconazole, the patient did not improve. The patient died 46 months after the diagnosis with septicemia due to Candida albicans (three positive blood cultures) and disseminated intravascular coagulation. Necropsy demonstrated disseminated paracoccidioidomycosis, with multiple spherical microorganisms and a large number of buds in the lungs and mesenteric lymph nodes.

\section{COMMENTS}

Gallium-67 citrate is a radiopharmaceutical that shows increased uptake in foci of inflammatory and infectious diseases and several malignant tumors. Gallium-67 scintigraphy has proven useful in the investigation of patients with fever of unknown origin, patients with suspected osteomyelitis and patients with impaired immunocompetence ${ }^{3,11,12}$. It accumulates in infections caused by pyogenic bacteria, mycobacteria and fungi.

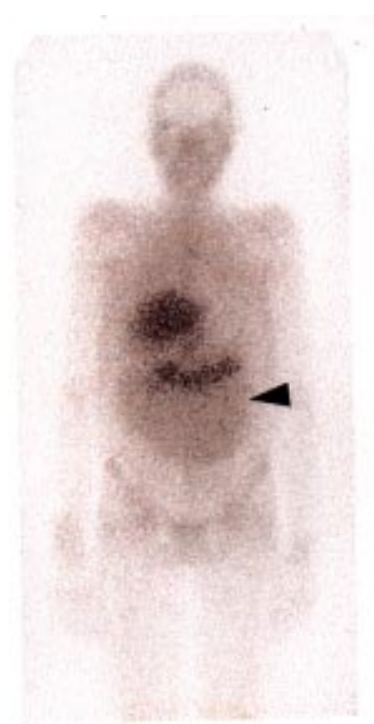

Fig. 5 - Whole-body scintigraphy (anterior view) obtained 31 months after the diagnosis show persistently increased uptake of gallium-67 in the abdomen (arrow head).

The use of gallium-67 scans in patients with paracoccidioidomycosis and other mycosis has already been described ${ }^{5-7,9}$. GIORGI et al. ${ }^{9}$, studying 13 patients with confirmed diagnosis of paracoccidioidomycosis, have shown that whole body gallium-67 imaging is a useful tool for detection of suspected and unsuspected lesions of paracoccidioidomycosis and helps to evaluate the response of the disease to specific therapy. These authors have shown good correlation between whole body gallium-67 scintigraphy and the clinical and laboratory findings. In some cases whole body gallium-67 scintigraphy was even more sensitive than the other methods for the diagnosis of lesion sites (e.g. gallium-67 imaging detected a brain lesion in one of the patients despite of normal CSF and neurologic examination; after appropriate therapy the follow-up study was normal).

In this case report there was also a good correlation between gallium67 imaging and the clinical history and prognosis. The areas of persistently increased tracer uptake correlated well with the patient's poor response to the treatment, which lead to her death.

\section{RESUMO}

\section{Pesquisa de corpo inteiro com gálio-67 em uma paciente com paracoccidioidomicose: relato de caso}

Paciente do sexo feminino de 26 anos foi internada com dor abdominal, febre e emagrecimento. A investigação clínico-laboratorial estabeleceu o diagnóstico de paracoccidioidomicose. Os achados cintilográficos com citrato de gálio-67 correlacionaram-se com o curso clínico da paciente. 
TEIXEIRA, A.B.M.J.; ETCHEBEHERE, E.C.S.C.; LIMA, M.C.L.; SANTOS, A.O.; PIRES, B.C.; VALENÇA JR., J.T.; RAMOS, C.D. \& CAMARGO, E.E. - Gallium-67 imaging in a patient with paracoccidioidomycosis: a case report. Rev. Inst. Med. trop. S. Paulo, 42(3):167-170, 2000.

\section{REFERENCES}

1. BARBOSA, W. - Paracoccidioidomicose (Blastomicose sul-americana). In: AMATO NETO, V. \& BALDY, J.L.S., ed. Doenças transmissíveis. 3. ed. São Paulo, Sarvier, 1989. p. 653-662.

2. BARBOSA, W. \& DAHER, R.R. - Blastomicose sul-americana (Paracoccidioidomicose). In: VERONESI, R.; FOCACCIA, R. \& DIETZE, R., ed. Doenças infecciosas e parasitárias. 8. ed. São Paulo, Guanabara-Koogan, 1995. p. 634-646

3. BECKER, W. - The contribution of nuclear medicine to the patient with infection. Europ. J. nucl. Med., 22: 1195-1211, 1995.

4. BETHLEM, N.M.; LEMLE, A.; BETHLEM, E. \& WANKE, B. - Paracoccidioidomycosis. Semin. resp. Med., 12: 81-97, 1991.

5. BRAGA, F.J.H.N.; ABREU, P.R.; RIVITTI, M.C.M. et al. - La paracoccidioidomycose chéloïde étudiée avec le gallium. Bull. Soc. Path. exot., 85: 118-119, 1992.

6. BRAGA, F.J.H.N.; CAMARGO, E.E.; SEGURADO, A.A.C. et al. - La paracoccidioidomycose évaluée par quatre études isotopiques. Bull. Soc. Path. exot., 85: 115-117, 1992.
7. DAYANIKI, B.F.; WEISSMAN, A.F. \& WAHL R.L. - Successful gallium-67 imaging of North American pulmonary blastomycosis. J. nucl. Med., 34: 958-960, 1993.

8. DEL NEGRO, G.M.B.; GARCIA, N.M.; RODRIGUES, E.G. et al. - The sensitivity, specificity and efficiency values of some serological tests used in the diagnosis of paracoccidioidomycosis. Rev. Inst. Med. trop. S. Paulo, 33: 277-280, 1991.

9. GIORGI, M.C.P.; CAMARGO, E.E.; PINTO, W.P. \& DEL NEGRO, G. - Gallium-67 imaging in the diagnosis of blastomycosis. Europ. J. nucl. Med., 13: 300-304, 1987.

10. NEGRONI, R. - Paracoccidioidomycosis. Int. J. Derm., 32: 847-859, 1993.

11. PALESTRO, C.J. - The current role of gallium imaging in infection. Semin. nucl. Med., 24: $128-141,1994$

12. PETERS, A.M. - The use of nuclear medicine in infections. Brit. J. Radiol., 71: 252$261,1998$.

Received: 24 August 1999

Accepted: 18 April 2000 